\title{
IN SITU RUMEN DEGRADATION KINETICS OF HIGH-PROTEIN FORAGE CROPS IN TEMPERATE CLIMATES
}

\author{
Ximena Valderrama L. ${ }^{1 *}$, and René Anrique G. ${ }^{1}$
}

The present study was conducted to evaluate the nutritional value and in situ degradation kinetics of eight high protein forage crops: alfalfa (Medicago sativa L.), forage oat (Avena sativa L.), mixed pasture, and ryegrass (Lolium multiflorum Lam.) pasture in early vegetative stages, two forage lupins (Lupinus albus L.) in early bloom stages, sugar beet (Beta vulgaris L.) and kale (Brassica napus var. pabularia (DC.) Rchb.) leaves at root maturity. Dry matter (DM) and crude protein $(\mathrm{CP})$ degradation kinetics were evaluated by the nylon bag technique through the in situ procedure described by Ørskov and MacDonald (1979) using three ruminally cannulated sheep. Chemical composition of the forage crops showed on average $13.7 \%$ DM; $21.4 \%$ CP; $31.5 \%$ neutral detergent fiber (NDF); $17.7 \%$ crude fiber (CF), $80.6 \%$ digestibility of organic matter (DOMD) and $12.13 \mathrm{MJ} \mathrm{kg}^{-1}$ metabolizable energy (ME). The high total degradability of forage crops reported here $(>87 \% \mathrm{DM} ;>93 \% \mathrm{CP})$ can be associated with the presence of large quantities of fraction $a(>34 \% \mathrm{DMa}$; $>29 \% \mathrm{CPa}$ ) and high degradability of fraction $b$, resulting in low amounts of undegradable fraction (U) (7.02\% DM and $3.55 \% \mathrm{CP})$. Correlations between $\mathrm{CPb}$ and $\mathrm{DMb}$ degradability $(\mathrm{r}=0.79)$ and $\mathrm{CPc}$ and $\mathrm{DMc}$ degradation rates $(\mathrm{r}=0.78)$ were high, however differences in $c$ were not explained by differences in CP or NDF contents, nor by the amounts of $a$ or $b$ fractions. Degradation for DM and CP during the first $6 \mathrm{~h}$ of incubation was strongly and inversely correlated to $b(36 \mathrm{~h})(\mathrm{r}$ $=0.93)(\mathrm{P}<0.0001)$ regardless of forage type. The amounts of $\mathrm{CPa}$ and $\mathrm{CPb}$ influenced effective degradability of $\mathrm{CP}(\mathrm{r}=$ 0.79; $\mathrm{P}<0.02)$, EDp increased with increased $\mathrm{CPa}$ and decreased with increased $\mathrm{CPb}(\mathrm{r}=0.76 ; \mathrm{P}<0.02)$. Therefore, more than $75 \%$ of the forage crops degraded within the first $6 \mathrm{~h}$ of incubation, which was associated with the DM content and amount of the slowly degradable fraction present.

Key words: Rumen, forage, rate of passage, chemical composition, degradability.

$\mathrm{T}$ he new methods used to estimate the protein value of food for ruminants are based on the characterization of nitrogenous fractions of the food and consider the rumen fermentation process. Protein fraction values allow for estimating the amount of dietary $\mathrm{N}$ available for microbial protein synthesis and the amount of $\mathrm{N}$ that escapes degradation in the rumen. Therefore, the real protein enzymatically digested and absorbed in the small intestine will be dependent on the dietary source and rumen fermentability of the feed (Kempton, 1980).

In southern Chile, pastures are the main source of nutrients for dairy, beef and sheep production. Since production systems work year-round, additional sources of feeds like silage and supplements are used in winter or under deficits of pasture availability to meet animal requirements. The nutritive value of the pasture changes in relation to fertilization, season, management, water availability, and stage of maturity (Chaves et al., 2006). As a result, crude protein $(\mathrm{CP})$ content is high in early

${ }^{1}$ Universidad Austral de Chile, Facultad de Ciencias Agrarias, Casilla 567, Valdivia, Chile. "Corresponding author (xvalderrama@uach.cl). Received: 9 March 2011.

Accepted: 16 September 2011. growth stages and decreases with maturity (Aufrère et al., 2000; 2003), which is related to decreasing CP content. The change in degradability is not consistent among forage species (Yu et al., 2004a). Immature forage crops contain more non-protein $\mathrm{N}$, primarily composed of ammonia, nitrate, amides, and free amino acids that are rapidly degradable in the rumen, therefore having less by-pass protein. With advancing maturity, protein synthesis continues and the cell wall matrix becomes more complex, rendering forage protein less degradable (Van Soest, 1994; Cherney et al., 2003).

When early grass growth stages are combined with high $\mathrm{N}$ fertilization, which is a common situation for most forage resources used in intensive production systems, soluble CP and non-protein N (NNP) contents increase and favor higher degradability of CP (Van Soest et al., 1978; Tremblay et al., 2005). Since microbial population growth is highly dependent on the availability of fermentable carbohydrates, its insufficient supply with respect to protein should reduce microbial protein synthesis, increasing $\mathrm{N}$ loss through urine and reducing the supply of amino acids (Hristov et al., 2005). The most limiting factor for efficient $\mathrm{N}$ utilization is the type and amount of carbohydrates available in the rumen. 
Besides the reduced availability of readily fermentable carbohydrates and the faster rates of degradation of protein compared to dry matter (DM) (Nocek and Russell, 1988), a greater lipid content in early growth stages should also limit available rumen energy and the efficient use of $\mathrm{N}$ in the rumen (AFRC, 1992).

The present study was designed to evaluate and characterize protein and DM rumen degradation dynamics of high protein forage crops using the in situ nylon bag technique in order to optimize the use of the nitrogenous fraction in animal feed formulations.

\section{MATERIALS AND METHODS}

Three sheep fitted with rumen fistula $(45 \pm 5 \mathrm{~kg})$ were used for this study. During the experimental period the animals were housed in individual pens. They were fed four times a day following a feeding schedule established in a previous study to keep rumen $\mathrm{pH}$ above 6.2. Hay was offered at 08:00 h, 16:00 h and a pellet mixture fed at 11:00 h, 19:00 h. The diet consisted of 40\% pasture hay and $60 \%$ of a mixture of equal parts of alfalfa pellets, a digestible fiber concentrate based on sugar beet pulp $(17 \% \mathrm{CP})$ and a starch concentrate based on cereal grains $(17 \% \mathrm{CP})$; intake was kept at $1.8 \%$ of body weight.

\section{In situ study}

The in situ DM and CP disappearance of rumen-incubated feeds was conducted according to the method of Ørskov and MacDonald (1979). Polyester bags $(14 \times 9 \mathrm{~cm}$ external diameter) (ANKOM100, Turk Hill Park, Fairport, New York, USA) of known weight and controlled porosity (40$60 \mu \mathrm{m}$ ) (Ørskov et al., 1980; Nocek, 1988) were used. For each bag $3 \mathrm{~g}$ sample was added to allow a ratio of sample to effective bag area of $16 \mathrm{mg} \mathrm{cm}^{-2}$. The bags were sealed with silicone paste after double sewing to avoid sharp edges and loss from stripping. Each forage species was evaluated by using five incubation periods $(0,2,6$, $12,24,36 \mathrm{~h}$ ), considering two replicates per time and per animal, with a total of six observations per time. As forage crops were in the early growth stages, with presumably high digestibility, the use incubation periods beyond 36 $\mathrm{h}$ was not considered necessary. Bags were incorporated to the rumen in reverse order to incubation time and all were extracted at the same time. After rinsing in cold water several times, bags containing forage residues were oven dried to a constant weight $\left(48 \mathrm{~h}, 60^{\circ} \mathrm{C}\right)$ before subsequent analysis (Mehrez and Orskov, 1977). CP and DM solubility was determined without incubation in the rumen (T0 h) by soaking the bags containing the samples in warm water $\left(40^{\circ} \mathrm{C}\right)$ for $20 \mathrm{~min}$, followed by drying as described.

\section{Sample preparation and chemical analysis}

The following forage species were studied: alfalfa (Medicago sativa L.), oat forage (Avena sativa L.), mixed pasture and rye grass (Lolium multiflorum Lam.) pasture, in early vegetative stages; two forage lupins (Lupinus albus L.) in early bloom stages, sugar beet (Beta vulgaris L.) and kale (Brassica napus var. pabularia (DC.) Rchb.) leaves at root maturity. Forage samples were freezedried and milled through a $5 \mathrm{~mm}$ screen for degradability studies and through a $1 \mathrm{~mm}$ screen for chemical analysis.

Forage species were analyzed for CP, DM, total ash (Ash), crude fiber (CF) (Cundiff, 1995), neutral detergent (NDF) and acid detergent fiber (ADF) and in vitro DM digestibility (DMOD) (Van Soest et al., 1991). Metabolizable energy (ME) was estimated by in vitro 48 $\mathrm{h}$ fermentation using rumen filtrated liquor and artificial saliva and then $48 \mathrm{~h}$ pepsin $+\mathrm{HCl}$ enzymatic digestion. Values for in vitro DOMD were associated to $\mathrm{ME}$ by regression $(\mathrm{ME}=0.325 \mathrm{DOMD}+0.279$; Garrido and Mann, 1981) (Table 1).

Table 1. Chemical composition of forages (DM basis).

\begin{tabular}{|c|c|c|c|c|c|c|c|}
\hline \multirow[t]{2}{*}{ Forage } & $\mathrm{DM}$ & $\mathrm{CP}$ & $\mathrm{CF}$ & NDF & \multicolumn{3}{|c|}{ ME DOMD DM } \\
\hline & & & & . & $\mathrm{MJ} \mathrm{kg}^{-1}$ & $-1-\%$ & \\
\hline Vegetative kale leaves & 11.3 & 22.5 & 12.4 & 19.1 & 13.0 & 87.3 & 4.8 \\
\hline Vegetative alfalfa & 15.5 & 26.2 & 18.9 & 29.6 & 11.1 & 73.2 & 9.2 \\
\hline Lupin plant, early bloom $(\mathrm{O})$ & 13.9 & 17.1 & 18.7 & 29.0 & 12.0 & 81.2 & 4.9 \\
\hline Lupin plant, mid bloom (L) & 12.5 & 14.9 & 19.3 & 27.7 & 12.2 & 80.8 & 4.9 \\
\hline Vegetative mixed pasture & 16.2 & 27.4 & 19.4 & 37.7 & 12.1 & 80.5 & 11.4 \\
\hline Vegetative oat forage & 14.7 & 20.8 & 23.0 & 40.5 & 12.5 & 83.6 & 8.2 \\
\hline Vegetative ryegrass pasture & 13.9 & 22.6 & 20.1 & 39.1 & 11.9 & 79.1 & 8.9 \\
\hline Sugar beet leaves & 11.2 & 19.6 & 9.8 & 29.5 & 11.9 & 79.0 & 13.6 \\
\hline
\end{tabular}

DOMD: in vitro digestibility of organic matter; DM: dry matter; CP: crude protein; CF: crude fiber; NDF: neutral detergent fiber; ME: metabolizable energy.

\section{In situ forage residue analysis}

In situ DM and CP recovery data were fitted to the model of Ørskov and MacDonald (1979) using a nonlinear regression procedure: $\mathrm{p}=\mathrm{a}+\mathrm{b}\left(1-\mathrm{e}^{-\mathrm{ct}}\right), p$ being the percentage of $\mathrm{CP}$ or $\mathrm{DM}$ degradation. The formula considers two $\mathrm{N}$ fractions in the feed: where $a$ is the soluble (or rapidly degraded) fraction, $b$ is the slowly degradable (or potentially degradable) fraction and $c$ is the rate of degradation of fraction $b\left(\mathrm{~h}^{-1}\right)$ in the rumen.

The undegradable fraction $U$ was calculated as: $U=100$ $-(a+b)$, at an exponential reducing rate $\left(e^{-c t}\right)$. Effective degradability (ED) of CP and DM was calculated as; ED = $\mathrm{a}+[(\mathrm{b} \times \mathrm{c}) /(\mathrm{c}+\mathrm{k})]$ according to Ørskov and Ryle (1990), assuming constant passage rates from the rumen $(\mathrm{k})$ of $0.02,0.05$, and $0.08 \mathrm{~h}^{-1}$ for each ingredient. Determination of degradability values and statistical analysis were performed by non-linear regression (Quasi-Newton) and the SYSTAT (1990) program. Regression analysis was used to establish the relationship between chemical composition and the proportions of the different fractions degraded over time and with in situ ED of CP.

\section{RESULTS AND DISCUSSION}

Forage chemical composition showed on average low DM $(13.7 \%)$, high protein $(21.4 \% \mathrm{CP})$, low fiber 
(31.5\% NDF, $17.7 \% \mathrm{CF})$ and high digestibility and energy contents (80.6\% DOMD and 12.13 MJ ME kg-1 DM) (Table 1). The high protein and low fiber and DM content of the forage crops were in accordance with the early vegetative stages at which they were harvested. With the exception of lupin, the CP content of individual forage crops was above $20 \%$. The two lupin forage crops had different CP contents, but similar NDF, ADF, $\mathrm{CF}$, digestibility, $\mathrm{ME}$, and ash contents. The high ash content in sugar beet leaves could be explained by soil contamination and the only affect could be a reduced DOMD value. The high digestibility of the different forage crops is attributed to the low fiber content due to low plant maturity or, in the case of kale and sugar beet, the high proportion of leaves.

\section{Degradation kinetics}

The kinetics of $\mathrm{CP}$ degradation was characterized by differences among forage crops in the soluble fraction (a) and slowly degradable fraction (b), with small differences in the undegradable fraction $(U)$ and potential degradability $(\mathrm{a}+\mathrm{b})$ (Table 2$)$. The high protein $(95 \%)$ and DM $(93 \%)$ degradability and the similar values among forage crops $(C P$ SD $=1.89$ and $\mathrm{DM} \mathrm{SD}=2.35$ ) in early vegetative stages suggests that very low proportions of the two components were degraded beyond the rumen, as has also been supported by Nocek and Russell (1988), Elizalde et al. (1999), and Aufrère et al. (2000) (Figure 1). Similarities in DM and PC degradability were found between legumes (alfalfa, lupin) and grasses (ryegrass, mixed pasture, and oat forage), which is consistent with the results reported by Peteva-Vancheva et al. (1990), MAFF (1990), and Flachowsky et al. (1992).

It has been demonstrated that the growth stage affects nutrient degradability in the rumen (Aufrère et al., 2003; Yu et al., 2004b). Fresh forage is degraded extensively in the rumen but the distribution of morphological components is not the same, resulting in a differential degradation of nutrient fractions in the rumen. PetevaVancheva et al. (1990) and Vanzant et al. (1996) predicted high CP degradability for alfalfa $(83.4 \%$ and $90 \%$, respectively). Our results were slightly higher (95.5\%), which could be due to the predominance of low lignin stems. Antoniewicz et al. (1995) reported values of $92.5 \%$ for early vegetative stage and $96.1 \%$ at full bloom of alfalfa. Other authors indicate that in general legumes can reach values of protein degradability up to $93 \%$ (López et al., 1991).

The high potential degradability of forage crops reported here $(>87 \% \mathrm{DM}$ and $>93 \% \mathrm{CP}$ ) could be associated with the presence of large quantities of soluble fraction $a$ (> 34\% DMa and > 29\% CPa) and high degradability of slowly degradable fraction $b$, resulting in low amounts of undegradable fraction $U(7.02 \% \mathrm{DM}$ and $3.55 \% \mathrm{CP}$ ) (Table 2). However, alfalfa and oat forage had higher than average DM $U$ fraction, which could be due to reduced degradability of fraction $b$ in both forage crops and to lower DOMD in alfalfa. Greater differences were found between soluble $a$ and slowly degradable $b$

Table 2. Degradation fractions (a,b, U) and effective degradability (ED) of crude protein (CP) and dry matter (DM) of high protein forages (\%) at ruminal outflow rates of $0.02,0.05$ and $0.08 \mathrm{~h}^{-1}$.

\begin{tabular}{|c|c|c|c|c|c|c|c|c|}
\hline Forage $\mathrm{CP}$ & $\mathrm{a}$ & $\mathrm{B}$ & $\mathrm{U}$ & $a+b$ & $\mathrm{c}$ & $\begin{array}{c}\text { EDp } \\
\mathrm{k}=0.02 \mathrm{~h}^{-1}\end{array}$ & $\begin{array}{c}\mathrm{EDp} \\
\mathrm{k}=0.05 \mathrm{~h}^{-1}\end{array}$ & $\begin{array}{c}\text { EDp } \\
\mathrm{k}=0.08 \mathrm{~h}^{-1}\end{array}$ \\
\hline & $\longrightarrow$ & 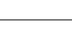 & 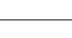 & - & $\% \mathrm{~h}^{-1}$ & & & \\
\hline Vegetative kale leaves & 31.22 & 66.40 & 2.38 & 97.62 & 0.162 & 90.32 & 81.96 & 75.67 \\
\hline Vegetative alfalfa & 56.69 & 35.82 & 4.49 & 95.51 & 0.197 & 92.20 & 88.25 & 85.16 \\
\hline Lupin plant early bloom (O) & 25.83 & 71.10 & 3.07 & 96.93 & 0.160 & 89.03 & 80.00 & 73.23 \\
\hline Lupin plant mid bloom (L) & 29.45 & 67.58 & 2.99 & 97.01 & 0.142 & 88.67 & 79.42 & 72.66 \\
\hline Vegetative mixed pasture & 33.39 & 64.03 & 2.58 & 97.42 & 0.314 & 93.58 & 88.62 & 84.42 \\
\hline Vegetative oat forage & 68.47 & 28.40 & 3.13 & 96.87 & 0.294 & 95.06 & 92.75 & 90.80 \\
\hline Vegetative ryegrass pasture & 49.05 & 47.66 & 3.29 & 96.71 & 0.157 & 91.33 & 85.20 & 80.62 \\
\hline Sugar beet leaves & 47.26 & 46.26 & 6.48 & 93.52 & 0.164 & 88.50 & 82.72 & 78.36 \\
\hline CP Average & 42.67 & 53.41 & 3.55 & 96.55 & 0.20 & 91.09 & 84.87 & 80.12 \\
\hline Standard Deviation & 11.76 & 10.74 & 1.89 & 1.89 & 0.08 & 3.29 & 5.22 & 6.63 \\
\hline Forage DM & & & & & & $\begin{array}{c}\text { EDdm } \\
\mathrm{k}=0.02 \mathrm{~h}^{-1}\end{array}$ & $\begin{array}{c}\text { EDdm } \\
\mathrm{k}=0.05 \mathrm{~h}^{-1}\end{array}$ & $\begin{array}{c}\text { EDdm } \\
\mathrm{k}=0.08 \mathrm{~h}^{-1}\end{array}$ \\
\hline Vegetative kale leaves & 34.91 & 62.00 & 3.09 & 96.91 & 0.166 & 90.25 & 82.56 & 76.75 \\
\hline Vegetative alfalfa & 47.62 & 40.02 & 12.36 & 87.64 & 0.142 & 82.70 & 77.22 & 73.22 \\
\hline Lupin plant early bloom $(\mathrm{O})$ & 40.63 & 51.37 & 8.00 & 92.00 & 0.152 & 86.03 & 79.29 & 74.29 \\
\hline Lupin plant mid bloom (L) & 38.73 & 55.36 & 5.91 & 94.09 & 0.121 & 86.24 & 77.90 & 72.08 \\
\hline Vegetative mixed pasture & 34.63 & 59.47 & 5.90 & 94.10 & 0.182 & 88.21 & 81.28 & 75.94 \\
\hline Vegetative oat forage & 46.62 & 43.82 & 9.56 & 90.40 & 0.232 & 86.98 & 82.67 & 79.21 \\
\hline Vegetative ryegrass pasture & 44.16 & 50.74 & 5.10 & 94.90 & 0.123 & 87.80 & 80.23 & 74.90 \\
\hline Sugar beet leaves & 53.68 & 40.12 & 6.20 & 93.80 & 0.165 & 89.46 & 84.47 & 80.70 \\
\hline DM Average & 42.62 & 50.36 & 7.02 & 92.98 & 0.160 & 87.21 & 80.70 & 75.89 \\
\hline Standard deviation & 4.94 & 5.36 & 2.32 & 2.35 & 0.05 & 1.26 & 2.13 & 3.01 \\
\hline
\end{tabular}

a: soluble fraction, b: slowly degraded fraction, $\mathrm{U}$ : insoluble fraction, c: degradation rate of fraction b, EDp: effective degradability of protein, EDdm: effective degradability of dry matter. 


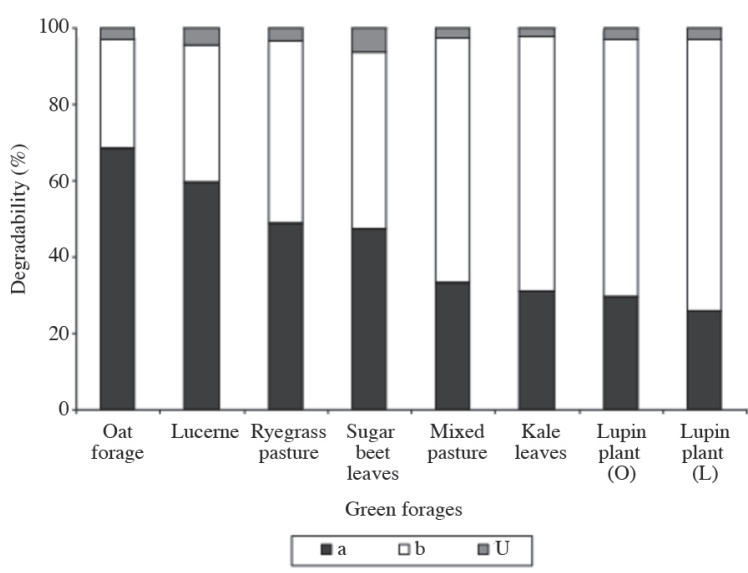

Figure 1. Crude protein degradable fractions of high protein green forages. a: soluble $(\square)$, b: slowly degradable $(\square)$ and U: insoluble ( $\square$ ).

fractions between $\mathrm{CP}$ and DM. The soluble $\mathrm{CP}$ fraction $(\mathrm{CPa})$ presented the highest standard deviation (11.8) among forage crops, ranging from $68.47 \%$ (oat forage) to $25.8 \%$ (lupin plant in early bloom) and was three times as high as DMa (4.94\%).

The $U$ fraction of DM for most forage crops was twice as high as that observed for $\mathrm{CP}$ and $\mathrm{CPc}$ (average $0.200 \mathrm{~h}^{-1}$ ) and was on average $23 \%$ greater than the average DMc $\left(0.16 \mathrm{~h}^{-1}\right)$, suggesting that little CP was bound to the cell wall and most of it was in the cell content as mitochondria and chloroplasts (Tamminga et al., 1991). This could explain the high $\mathrm{CPb}$ degradability rate $c$ for oat forage $\left(0.29 \mathrm{~h}^{-1}\right)$ considering its high DM $\mathrm{U}$ fraction $(9.56 \%)$ in comparison to alfalfa, where rate of degradability decreased in the presence of high DM $\mathrm{U}$ fraction (12.4\%) indicating that the proportion of $\mathrm{CP}$ bound to cell wall could be higher. Faster degradation rates than average for $\mathrm{CPc}$ were observed in oat forage $\left(0.294 \% \mathrm{~h}^{-1}\right)$ and mixed pasture $\left(0.314 \% \mathrm{~h}^{-1}\right)$. The DMc for oat forage DM $\left(0.23 \mathrm{~h}^{-1}\right)$ was again the most rapidly degraded, lupin plant was the most slowly degraded $\left(0.12 \% \mathrm{~h}^{-1}\right)$. High differences between CPc and DMc were observed in mixed pasture $(+73 \%)$ and alfalfa $(+39 \%)$, followed by ryegrass pasture and oat forage $(+27 \%)$. Similar degradation rates for CP and DM resulted for lupin forage, kale leaves and sugar beet leaves (Table 2). Predicted $c$ by Flachowsky et al. (1992) and López et al. (1991) for alfalfa $\left(0.14 \% \mathrm{~h}^{-1}\right)$, lupin $\left(0.12 \% \mathrm{~h}^{-1}\right)$ and white clover $\left(0.12 \% \mathrm{~h}^{-1}\right)$ were similar to those determined in this study.

Nutrient composition (DM, CP and NDF) was not highly correlated with $c$. However, $\mathrm{CPc}$ and $\mathrm{DMc}$ rates were highly correlated $(r=0.78)$ (Figure $2 \mathrm{~A})$. This could be a consequence of low FDN and probably a low proportion of $\mathrm{N}$ bound to the cell wall. Protein degradation rates did not completely explain the amount of $\mathrm{CPa}$ or $\mathrm{CPb}$ fraction, as shown by the low correlation values. Meanwhile, the higher mean degradability for $\mathrm{CP}$ compared to $\mathrm{DM}$
$(+3.7 \%)$ could be explained by the elevated degradation of $\mathrm{CP}(+23 \%)$. CP and DM degradability were positively correlated $(r=0.79)$ (Figure $2 \mathrm{~B})$, however differences in degradation rates were not explained by differences in $\mathrm{CP}$ or NDF contents, nor by the amounts of $a$ or $b$ fractions. This indicates that in grasses or legumes of high protein contents and high digestibility, the amount of NDF does not limit CP degradability. Therefore, factors explaining differences in CPc among forage crops should be further studied using a more discriminating approach with respect to $\mathrm{N}$ and carbohydrate fractions, as shown by $\mathrm{Yu}$ et al. (2004a).

\section{Degradation of slowly degradable fraction $\boldsymbol{b}$ in time}

Degraded proportions of fraction $b$ among forage crops, along with incubation periods, were variable (Figure 2A and 2B). Most part of fraction $b$ disappeared within the first $6 \mathrm{~h}$ of incubation $(\mathrm{CPb}: 57.7-84.8 \%$ and DMb: 52.3-75.2\%) regardless of fraction size. After 6 $\mathrm{h}$ of incubation, more than $80 \%$ of $\mathrm{CPb}$ was degraded in mixed pasture and oat forage, which presented the highest degradation rates $\left(0.314 \% \mathrm{~h}^{-1}\right.$ and $\left.0.294 \% \mathrm{~h}^{-1}\right)$. As well, the proportion degraded during this period correlated strongly and inversely $(\mathrm{P}<0.0001)$ with the total amount of $b(\mathrm{r}=0.93)$ for $\mathrm{DM}$ and $\mathrm{CP}$, regardless of forage type. $\mathrm{On}$ average, $68 \%$ of $\mathrm{CPb}$ (Figure 2A) and $61 \%$ of $\mathrm{DMb}$ (Figure 2B) was degraded at $6 \mathrm{~h}$ of incubation. Correlations of $\mathrm{CPc}$ with $\mathrm{CP}$, fraction $a$ and $b$ were low. Therefore, there might be other factors affecting early degradability of CP. Although forage crops responded differently in terms of CP compared to $\mathrm{DM}$ degradability of fraction $b$, the $\mathrm{DMb}$ degradability fraction is explained mainly by $\mathrm{CPb}$ degradability $(\mathrm{r}=$ $0.79)$ and the rate of degradation $(r=0.79)$ was positive and significant $(\mathrm{P}<0.02)$. Differences in degradation rates could be due to amounts of intracellular components and digestibility, while $\mathrm{N}$ availability is due to its distribution among cell structures. In fact, it has been reported that neutral detergent insoluble N (NDIN) requires a greater lag time for degradation than the $\mathrm{N}$ pool, regardless of forage type and maturity (Coblentz et al., 1999). On the other hand, intracellular $\mathrm{N}$ is quickly available (1-2 h) and diminishes rapidly with time (Aufrère et al., 2000). Under these conditions, the high degree degradability observed during the first $6 \mathrm{~h}$ of fermentation could be associated with low NDIN in mixed pasture and oat forage, and therefore the higher content of NDF was not a limiting factor for degradation (Table 1). The slower rates of degradation found in lupin in early bloom and kale leaf could be influenced by a higher proportion of ADIN, despite its low NDF and higher $b$ fraction. In general, the results indicate that as incubation time increased, differences in degradability among forage crops decreased, reaching nearly $90 \%$ of the degradable $\mathrm{CPb}$ and $85 \%$ of $\mathrm{DMb}$ fractions in just $12 \mathrm{~h}$. 
A

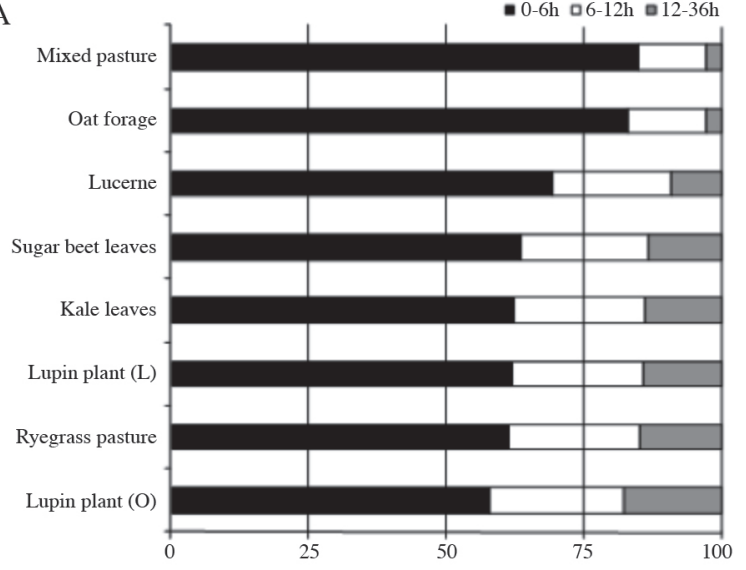

B

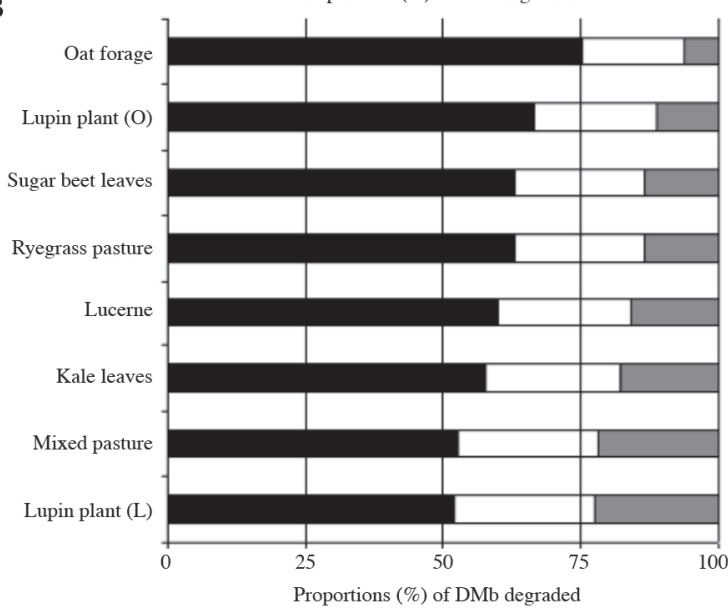

Figure 2. Characterization of slowly degradable fraction (b) in green forages. A) Proportions (\%) of crude protein (CP) slowly degradable fraction (b) at different incubation times $(\square 0-6 \mathrm{~h}, \square$ 6-12 h, and $\square$ 12-36 h). B) Proportions (\%) of dry matter (DM) slowly degradable fraction (b) at different incubation times ( $\square$ 0-6 h, $\square$ 6-12 h, and $\square$ 12-36 h).

\section{Effective degradability (ED)}

Differences in ED among forage crops can be explained by differences in the amount of fraction $a, b$ and $c$. A significant correlation was found between $\mathrm{CPa}$ and $\mathrm{EDp}$ $(\mathrm{r}=0.79 ; \mathrm{P}<0.02)$, showing that EDp increased by $0.23 \%$ units for each unit of increment in $\mathrm{CPa}$ content. Conversely, as the amount of $\mathrm{CPb}$ increased, $\mathrm{EDp}$ values decreased $(\mathrm{r}=0.76 ; \mathrm{P}<0.02)$ at a rate of $0.21 \%$ units for each unit of increase $b$ fraction. Therefore, forage crops showing higher $a$ or lower $b$ fraction displayed higher EDp values, and were less affected by the outflow rate. As an example, the highest EDp and the lowest effect of the outflow rate was observed with oat forage, with the highest proportion of fraction $a(64.5 \%)$ and the lowest of fraction $b(28.4 \%)$, with only a $6.3 \%$ reduction of total degradability. For this reason, the two lupin forage crops that showed the lowest amount of fraction $a$, the highest of fraction $b$ and the lowest rates of $c$ were the most affected by increasing the outflow rate, reducing total degradability by $25 \%$ (Table 2 ). The same pattern was observed for DM (EDdm).

\section{CONCLUSIONS}

Potential degradability was more uniform among forage crops than was degradation kinetics, which were more related to the proportions of soluble and insoluble degradable fractions. No consistent differences in degradability were found between legumes and grasses.

Degradability was high (>90\%) for DM and CP, but greater and more variable for $\mathrm{CP}$. On average, degradability and degradation rates were higher for $\mathrm{CP}$ and most degradation occurred in the first $6 \mathrm{~h}$ of incubation. The proportion degraded during the first $6 \mathrm{~h}$ was highly, and inversely correlated to the slowly degradable fraction of $\mathrm{DM}$ and $\mathrm{CP}$, regardless of forage type. Maximum degradability was reached between 24 and $36 \mathrm{~h}$.

Effective degradability decreased as the rate of passage $(c)$ and the slowly degradable fraction $(b)$ increased, showing that degradability at a given rate of passage was more influenced by the magnitude of the insoluble degradable fraction. Forage crops rich in soluble $\mathrm{CP}$ or DM were the least affected by passage rate.

\section{ACKNOWLEDGEMENTS}

The authors thank the Animal Nutrition Laboratory, Universidad Austral de Chile for technical support and chemical analysis and the Fondo Nacional de Desarrollo Científico y Tecnológico (FONDECYT-11080211) (Chile) for financial support.

Cinética de degradación ruminal in situ en forrajes de alto contenido proteico en clima templado. El presente estudio se desarrolló con el objetivo de evaluar el valor nutricional y la cinética de degradación in situ de ocho forrajes de alto valor proteico: alfalfa (Medicago sativa L.), avena (Avena sativa L.), pastos mixtos y pastos de ballica (Lolium multiflorum Lam.), en las primeras etapas vegetativas, dos lupinos forrajeros (Lupinus albus L.) en etapas inicio de la floración, hojas de remolacha azucarera (Beta vulgaris L.) y de col (Brassica napus var. pabularia (DC.) Rchb.) La cinética de degradación ruminal de la materia seca $(\mathrm{DM})$ y proteína cruda $(\mathrm{CP})$ se evaluaron mediante la técnica in situ de la bolsa de nylon descrita por Ørskov MacDonald (1979), con tres ovejas-fistuladas, en cinco tiempos de incubación. La composición química de los forrajes fue en promedio 13,7\% DM, CP 21,4\%; $31,5 \%$ de fibra detergente neutro (NDF), 17,7\% fibra cruda (CF); digestibilidad de la materia orgánica (DOMD) $80,6 \%$ y $12,13 \mathrm{MJ} \mathrm{kg}^{-1}$ energía metabolizable (ME). La degradabilidad total de los forrajes fue alta (> 87\% DM; $>93 \% \mathrm{CP}$ ) asociada a la presencia de grandes cantidades 
de la fracción $a$ (> 34\% DMa; $>29 \% \mathrm{CPa}$ ) y a la alta degradabilidad de la fracción $b$, determinando cantidades bajas de la fracción no degradable (U) (7,02\% DM y $3,55 \% \mathrm{CP}$ ). Las correlaciones entre la degradabilidad $\mathrm{CPb}$ y $\mathrm{DMb}(\mathrm{r}=0,79)$ y entre $\mathrm{CPc}$ y $\mathrm{DMc}(\mathrm{r}=0,78)$ fueron altas; sin embargo, las diferencias en $c$ no se explican por las diferencias en $\mathrm{CP}$ o contenido de NDF, ni por la cantidad de fracciones de $a$ o $b$. La degradación de DM y CP durante las primeras $6 \mathrm{~h}$ de incubación se correlacionó inversamente con $b(36 \mathrm{~h})(\mathrm{r}=0,93 ; \mathrm{P}<$ 0,0001 ), independiente del tipo de forraje. La cantidad de $\mathrm{CPa}$ y $\mathrm{CPb}$ influenció la degradabilidad efectiva de $\mathrm{CP}(\mathrm{r}=0,79 ; \mathrm{P}<0,02)$, al aumentar CPa también lo hizo DEp y, disminuyó al aumentar la $\mathrm{CPb}(\mathrm{r}=0,76 ; \mathrm{P}<0,02)$. Por lo tanto, la PC y MS de estos forrajes se degradó en más del 75\% en las primeras 6 h de incubación y esto puede asociarse con el contenido de DM y la cantidad de fracción lentamente degradable presente.

Palabras clave: rumen, forraje, tasa de pasaje, composición química, degradabilidad.

\section{LITERATURE CITED}

AFRC. 1992. Technical committee on responses to nutrients. Report $\mathrm{N}^{\circ}$ 9. Nutritive requirements of ruminant animals. Protein. Nutritional Abstracts and Review Series B vol. 62. p. 787-835. CAB International, Wallingford, Oxon, UK.

Antoniewicz, A.M., J. Kowalczyk, J. Kanski, Z. Gorska-Matusiak, and M. Nalepka. 1995. Rumen degradability of crude protein of dried grass and lucerne forage measured by in sacco incubation and predicted by near infrared spectroscopy. Animal Feed Science and Technology 54:203-216.

Aufrère, J., D. Graviou, R. Baumont, A. Detour, and C. Demarquilly. 2000. Degradation in the rumen of proteins from fresh lucerne forage in various stages of growth and conserved as silage or hay. Annales de Zotechnie 49:462-474.

Aufrère, J., D. Graviou, and C. Demarquilly. 2003. Ruminal degradation of protein of cocksfoot and perennial ryegrass as affected by various stages of growth and conservation methods. Animal Research 52:245-261.

Chaves, A.V., G.C. Waghorn, I.M. Brookes, and D.R. Woodfield. 2006. Effect of maturation and initial harvest dates on the nutritive characteristics of ryegrass. Animal Feed Science and Technology 127:293-318.

Cherney, D.J.R., J.H. Cherney, and R.F. Lucey. 2003. In vitro digestion kinetics and quality of perennial grasses as influenced by forage maturity. Journal of Dairy Science 76:790-797.

Coblentz, W.K., J.O. Fritz, W.H. Fick, R.C. Cochran, J.E. Shirley, and J.E. Turner. 1999. In situ disappearance of neutral detergent insoluble nitrogen from alfalfa and eastern gamagrass at three maturities. Journal of Animal Science 77:2803-2809.

Cundiff, P. 1995. Official methods of analysis of AOAC-International. $16^{\text {th }}$ ed. AOAC-International, Arlington, Virginia, USA.

Elizalde, J.C., N.R. Merchen, and D.B. Faulkner. 1999. Fractionation of fiber and crude protein in fresh forages during the spring growth. Journal of Animal Science 77:476-484.

Flachowsky, G., M. Schneider, K. Tirike, and H. Koch. 1992. Intake of in sacco dry matter degradability and apparent digestibility on artificial dried Italian ryegrass and white clover in sheep. Wirtschaftseigen Futter 38:1-24.

Garrido, O., y E. Mann. 1981. Composición química, digestibilidad y valor energético de una pradera permanente de pastoreo a través del año. 63 p. Tesis Ingeniero Agrónomo. Universidad Austral de
Chile, Facultad de Ciencias Agrarias, Valdivia, Chile.

Hristov, A.N., J.K. Ropp, K.L. Grandeen, S. Abedi, R.P. Etter, A. Melgar, and A.E. Foley. 2005. Effect of carbohydrate source on ammonia utilization in lactating dairy cows. Journal of Animal Science 83:408-421.

Kempton, T.J. 1980. El uso de bolsas de nylon para caracterizar el potencial de degradabilidad de alimentos para el rumiante. Producción Animal Tropical 5:115.

López, S., M.D. Carro, J.S. González, and F.J. Ovejero. 1991. The effect of method of forage conservation and harvest season on the rumen degradation of forages harvested from permanent mountain meadows. Animal Production 53:177-182.

MAFF. 1990. Table of nutritive value and chemical composition of feeding stuffs. 420 p. Rowett Research Services Limited, Aberdeen, UK.

Mehrez, A.Z., and E.R. Orskov. 1977. A study of artificial bag technique for determining the digestibility of feed in the rumen. Journal of Agricultural Science 88:645-650.

Nocek, J.E. 1988. In situ and other methods to estimate ruminal protein and energy digestibility: A review. Journal of Dairy Science 71:2051-2069.

Nocek, J.E., and J.B. Russell. 1988. Protein and energy as an integrated system. Relationship of ruminal protein and carbohydrate availability to microbial synthesis and milk production. Journal of Dairy Science 71:2070-2107.

Ørskov, E.R., F.D. Howell, and F. Mould. 1980. The use of the nylon bag technique for the evaluation of feedstuffs. Tropical Animal Production 5:195-213.

Ørskov, E.R., and I. McDonald. 1979. The estimate of protein degradability in the rumen from incubation measurements weighted according to rate of passage. Journal of Agricultural Science 92:499-503.

Ørskov, E.R., and M. Ryle. 1990. Energy nutrition in ruminants. p. 133-143. Elsevier Science Ltd., Essex, UK.

Peteva-Vancheva, Z., F. Iliev, B. Aleksandrov, and X. Shindarska. 1990. Degradation in the rumen of wethers of protein and dry matter of green Lucerne, harvested at different phases of vegetation, studied using nylon bag technique. Zhivotnov'dni Nauki 27(8):62-67.

SYSTAT. 1990. SYSTAT: The system for statistics. Version 5. Systat Corporation, Evanston, Illinois, USA.

Tamminga, J.A., R. Ketelaar, and A.M. Van Vuuren. 1991. Degradation of nitrogenous compounds in conserved forages in the rumen of dairy cows. Grass and Forage Science 46:427-435.

Tremblay, G.F., G. Bélanger, and R. Drapeau. 2005. Nitrogen fertilizer application and developmental stage affect silage quality of timothy (Phleum pratense L.) Grass Forage Science 60:337355.

Van Soest, P.J. 1994. Nutritional ecology of the ruminant. $2^{\text {nd }}$ ed. Cornell University Press, Ithaca, New York, USA.

Van Soest, P.J., D.R. Mertens, and B. Deinum. 1978. Preharvest factors influencing quality of conserved forage. Journal of Animal Science 47:712-720.

Van Soest, P.J., J.B. Robertson, and B.A. Lewis. 1991. Methods for dietary fiber, neutral detergent fiber and non-starch polysaccharides in relation to animal nutrition. Journal of Dairy Science 74:3583-3597.

Vanzant, E.S., R.C. Cochran, E.C. Titgemeyer, S.D. Stafford, K.C. Olson, D.E. Johnson, and G. St. Jean. 1996. In vivo and in situ measurements of forage protein degradation in beef cattle. Journal of Animal Science 74:2773-2784.

Yu, P., D.A. Christensen, and J.J. McKinnon. 2004a. In situ rumen degradation kinetics of timothy and alfalfa as affected by cultivar and stage of maturity. Canadian Journal of Animal Science $84: 255-263$

Yu, P., J.J. McKinnon, and D.A. Christensen. 2004b. The ratios of degradation characteristics of forages in the rumen of dairy cows: effect of variety and stage of maturity. Journal of the Science of Food and Agriculture 84:179-189. 